\title{
Staging lung cancer: role of endobronchial ultrasound
}

\author{
This article was published in the following Dove Press journal: \\ Lung Cancer: Targets and Therapy \\ 4 November 2014 \\ Number of times this article has been viewed
}

\section{Terunaga Inage \\ Takahiro Nakajima \\ Ichiro Yoshino}

Department of General Thoracic Surgery, Graduate School of Medicine, Chiba University, Chiba, Japan
Correspondence: Takahiro Nakajima Department of General Thoracic Surgery, Graduate School of Medicine, Chiba University, I-8-I Inohana, Chuo-ku, Chiba 260-8670, Japan

$\mathrm{Tel}+8|432227| 7 \mid$ ext 5464

Fax $+8 \mid 432262172$

Email tnakajima76@hotmail.com
Abstract: Accurate staging is the first step in the management of lung cancer. Nodal staging is quite important for physicians to be able to judge the primary operability of patients harboring no distant metastasis. For many years, mediastinoscopy has been considered a "gold standard" modality for nodal staging. Mediastinoscopy is known to be a highly sensitive procedure for mediastinal staging and has been performed worldwide, but is invasive. Because of this, clinicians have sought a less invasive modality for nodal staging. Endobronchial ultrasound-guided transbronchial needle aspiration (EBUS-TBNA) is a minimally invasive modality for diagnosis and staging of lung cancer. EBUS-TBNA is a needle biopsy procedure that has accessibility compatible with the reach of the convex-probe EBUS scope, so N1 nodes are also assessable. The diagnostic yield is similar to that of mediastinoscopy, and the core obtained by the dedicated needle biopsy can be used for histological assessment to determine the subtypes of lung cancer. The samples can also be used to test for various biomarkers using immunohistochemistry, polymerase chain reaction for DNA/complementary DNA, and in situ hybridization, and the technique is useful for selecting candidates for specific molecular-targeted therapeutic agents. According to the newly published American College of Chest Physicians guideline, EBUSTBNA is now considered "the best first test" for nodal staging in patients with radiologically suspicious nodes. Appropriate training and thorough clinical experience is required to be able to perform correct nodal staging using this procedure.

Keywords: lung cancer, staging, endobronchial ultrasound, transbronchial biopsy

\section{Introduction}

Nodal staging is key in the management of early-stage lung cancer. The prognosis and primary operability of a patient is influenced by the presence of mediastinal lymph node metastasis. Nodal staging is usually initiated using noninvasive radiological modalities such as chest computed tomography (CT) and integrated positron emission tomography (PET)-CT. According to the third American College of Chest Physicians guideline on nodal staging, further invasive staging can be waived in patients with a small-sized peripheral primary tumor $(<3 \mathrm{~cm})$ and a radiologically normal mediastinum. ${ }^{1}$ In other cases, invasive staging modalities are required for tissue confirmation. Endobronchial ultrasound-guided transbronchial needle aspiration (EBUS-TBNA) was introduced in 2004 as a less invasive modality for the diagnosis of mediastinal and hilar lymph node metastasis. ${ }^{2}$ EBUS-TBNA can be performed on an outpatient basis under local anesthesia with conscious sedation. ${ }^{3}$ The accessibility is wider than with mediastinoscopy, which includes hilar lymph nodes. ${ }^{2}$ If combined with endoscopic ultrasound-guided fine needle aspiration (EUS-FNA), most of the mediastinal and hilar lymph nodes 
can be assessed. ${ }^{4}$ Several meta-analyses have confirmed that EBUS-TBNA is a diagnostic tool with high sensitivity and specificity in the detection of metastatic nodes adjacent to the tracheobronchial tree and it is also regarded as a safe and less invasive procedure..$^{5-7}$ Therefore, EBUS-TBNA is now widely accepted as a first-step procedure for confirmation of suspicious nodal disease in patients with lung cancer.

\section{Initial staging in lung cancer}

Staging of lung cancer begins with radiology. CT is usually used for initial evaluation of the disease. For nodal staging, the sensitivity, specificity, and diagnostic accuracy of chest CT scan is $68 \%, 65 \%$, and $66 \%$, respectively, if significant lymphadenopathy is defined as a short axis of $1 \mathrm{~cm}$ or more in size. ${ }^{8}$ PET using 18-fluorodeoxyglucose or PET-CT showed higher diagnostic accuracy than CT alone for mediastinal staging. ${ }^{9}$ A meta-analysis reported that PET-CT has a median sensitivity and specificity of $100 \%$ and $78 \%$ for enlarged lymph nodes $(>1 \mathrm{~cm})$, and $82 \%$ and $93 \%$ for normal-sized lymph nodes in detecting metastatic lymph nodes, respectively. ${ }^{1}$ There is a limitation for FDG-PET in that metastatic lesions less than $8 \mathrm{~mm}$ in diameter are likely to be reported as false negative. ${ }^{1}$ Due to such limitations, histological confirmation is recommended when nodal disease is suspected by radiology.

\section{Nodal staging by mediastinoscopy}

Mediastinoscopy has been a standard procedure for nodal staging in lung cancer, and is a minor surgery performed in the operating room under general anesthesia. ${ }^{10}$ Several systematic reviews and meta-analyses reported the yield of nodal staging for non-small cell lung cancer by mediastinoscopy to have a pooled sensitivity of $57 \%-96 \%$ and a pooled specificity of $100 \%{ }^{11}$ (Table 1 ). Complication rates are very low, but major complications, including bleeding, recurrent nerve paralysis, and mortality have been reported. ${ }^{12,13}$ Mediastinoscopy can access the major areas of the mediastinum and right station 10, but there is some difficulty reaching the posterior side of the subcarinal node (station 7).

\section{Nodal staging by EBUS-TBNA}

EBUS-TBNA is a minimally invasive modality for nodal staging in patients with lung cancer. This needle biopsy procedure shows high sensitivity and specificity. Several systematic reviews and meta-analyses have reported the yield of nodal staging for non-small cell lung cancer by EBUS-TBNA to have a pooled sensitivity of $88 \%-93 \%$ and a pooled specificity of $100 \% .^{5-7}$ In comparison with PET or PET-CT, the sensitivity, specificity, and accuracy of EBUSTBNA were superior. ${ }^{14,15}$

The accessibility of EBUS-TBNA is the same as the reach of the convex-probe EBUS scope, which includes the hilar nodes. Its utility for differentiating between N0 and N1 disease has also been reported. ${ }^{16}$ Lymph nodes that are away from the airway cannot be accessed, such as the prevascular nodes ( $3 a)$, the subaortic and para-aortic nodes (5 and 6), and the paraesophageal and pulmonary ligament

Table I Endobronchial ultrasound-guided transbronchial needle aspiration for nodal staging in patients with lung cancer

\begin{tabular}{|c|c|c|c|c|c|c|c|c|}
\hline Reference & Year & Patients & Sensitivity & Specificity & PPV & NPV & Stage & Safety \\
\hline Yasufuku et al $^{2}$ & 2004 & 70 & $96 \%$ & $100 \%$ & $100 \%$ & $92 \%$ & cNI-3 & No complication \\
\hline Yasufuku et al ${ }^{48}$ & 2005 & 108 & $95 \%$ & $100 \%$ & $100 \%$ & $90 \%$ & cNI-3 & No complication \\
\hline Herth et $\mathrm{a}^{49}$ & 2006 & 100 & $92 \%$ & $100 \%$ & $100 \%$ & $96 \%$ & cNo & No complication \\
\hline Yasufuku et al ${ }^{14}$ & 2006 & 120 & $92 \%$ & $100 \%$ & $100 \%$ & $97 \%$ & $\mathrm{cNI}-3$ & No complication \\
\hline Nakajima et $\mathrm{a}^{27}$ & 2007 & 43 & $92 \%$ & $100 \%$ & $100 \%$ & $90 \%$ & $\mathrm{cN} 0-3$ & No complication \\
\hline Herth et $\mathrm{a}^{50}$ & 2008 & 97 & $89 \%$ & $100 \%$ & $100 \%$ & $99 \%$ & $\mathrm{cNO}$ & No complication \\
\hline Lee et $\mathrm{al}^{51}$ & 2008 & 102 & $94 \%$ & $100 \%$ & $100 \%$ & $97 \%$ & cN2-3 & No complication \\
\hline Wallace et $\mathrm{al}^{52}$ & 2008 & 138 & $69 \%$ & $100 \%$ & $100 \%$ & $88 \%$ & cN2-3 & No complication \\
\hline Bauwens et $\mathrm{a}^{53}$ & 2008 & 106 & $95 \%$ & $100 \%$ & $100 \%$ & $91 \%$ & cNI-3 & No complication \\
\hline Hwangbo et $\mathrm{a}^{54}$ & 2009 & 117 & $90 \%$ & $100 \%$ & $100 \%$ & $97 \%$ & cN2-3 & No complication \\
\hline Szlubowski et al ${ }^{55}$ & 2009 & 226 & $89 \%$ & $100 \%$ & $100 \%$ & $84 \%$ & $\mathrm{cN} 0-3$ & No complication \\
\hline Rintoul et $\mathrm{al}^{56}$ & 2009 & 109 & $91 \%$ & $100 \%$ & $100 \%$ & $60 \%$ & cNI-3 & No complication \\
\hline Fielding et $\mathrm{al}^{57}$ & 2009 & 68 & $95 \%$ & $100 \%$ & $100 \%$ & $67 \%$ & cNI-3 & No complication \\
\hline Nakajima et al ${ }^{38}$ & 2010 & 49 & $67 \%$ & $100 \%$ & $100 \%$ & $93 \%$ & cNI-3 & No complication \\
\hline Herth et $\mathrm{a}^{58}$ & 2010 & 139 & $91 \%$ & $100 \%$ & $100 \%$ & $92 \%$ & cNI-3 & No complication \\
\hline Cerfolio et $\mathrm{al}^{59}$ & 2010 & 92 & $57 \%$ & $100 \%$ & $100 \%$ & $79 \%$ & $\mathrm{cN} 2$ & No complication \\
\hline Hwangbo et $\mathrm{a}^{60}$ & 2010 & 150 & $84 \%$ & $100 \%$ & $100 \%$ & $93 \%$ & cN2-3 & No complication \\
\hline Yasufuku et al ${ }^{19}$ & 2011 & 153 & $81 \%$ & $100 \%$ & $100 \%$ & $91 \%$ & cN0-3 & No complication \\
\hline Memoli et $\mathrm{a}^{61}$ & 2011 & 100 & $87 \%$ & $100 \%$ & $100 \%$ & $89 \%$ & cNI-3 & No complication \\
\hline Steinfort et $\mathrm{al}^{62}$ & 2011 & 117 & $95 \%$ & $100 \%$ & $100 \%$ & $83 \%$ & cNI-3 & No complication \\
\hline
\end{tabular}

Abbreviations: PPV, positive predictive value; NPV, negative predictive value. 
nodes (8 and 9). EUS-FNA via the esophagus can access stations 8 and 9; therefore, in combination of EBUS-TBNA and EUS-FNA, the majority of mediastinum and hilar area can be assessed by combined EBUS/EUS-NA. A higher diagnostic yield has been reported using a combination of EBUS-TBNA and EUS-FNA for nodal staging in lung cancer. ${ }^{8,17}$ In the ASTER trial, the combined needle biopsy modality of EBUS-TBNA plus EUS-FNA and surgical staging showed a higher diagnostic yield and fewer unnecessary thoracotomies compared with surgical staging alone. ${ }^{18}$

Recently, the diagnostic yield of EBUS-TBNA alone was proved to be similar to that of mediastinoscopy in a wellcontrolled prospective study of surgical candidates, ${ }^{19}$ this study suggested that mediastinoscopy could be replaced by EBUS-TBNA if performed by expert hands. A recently published guideline for invasive staging in lung cancer reported that ultrasound-guided needle biopsy (EBUS-TBNA and/or EUS-FNA) is the "best first test" prior to surgical staging; 20 however, if the needle biopsy shows negative results, further invasive staging such as mediastinoscopy or video-assisted surgery will be needed for confirmation of the result.

EBUS-TBNA can be used for nodal staging in patients with small cell lung cancer. Surgical indication for small cell lung cancer is limited to stage I disease, so diagnosis of N1 nodes is also important and EBUS-TBNA is very useful in this regard. It was reported that the sensitivity, specificity, and diagnostic accuracy rate of EBUS-TBNA for small cell lung cancer is $96.4 \%, 100 \%$, and $97.2 \%$, respectively. ${ }^{21}$

\section{Restaging in lung cancer}

After induction treatment using chemotherapy and/or radiotherapy, we often find that we need to restage the lymph nodes. Repeat mediastinoscopy is possible; ${ }^{22}$ however, the diagnostic yield is not as high as the initial mediastinoscopy due to technical difficulties caused by adhesions. ${ }^{23}$ EBUS-TBNA can be repeated during and after treatment. Because of the limitations of the needle biopsy procedure, the diagnostic yield for restaging is not as high as for the initial EBUS-TBNA, which is the same as mediastinoscopy. ${ }^{22}$ Although it has a lower diagnostic yield for restaging, EBUS-TBNA is minimally invasive and is still of value as a restaging procedure.

\section{Diagnosis of recurrent nodal disease}

EBUS-TBNA is also useful for diagnosis of lymph node recurrence after treatment for lung cancer. ${ }^{24}$ This is because swollen nodes due to benign entities or neoplasms other than the previous lung cancer are at times encountered. In our experience, benign adenopathy is often recognized after surgery. ${ }^{25}$ Lymph node inflammation after surgery is mimics cancer recurrence by radiology, and tissue confirmation by mediastinoscopy or video-assisted thoracic surgery is difficult due to adhesions after surgery. Hence, EBUS-TBNA can be a useful procedure for diagnosis of post-surgical nodal recurrence. ${ }^{26}$

\section{Subtyping of lung cancer and biomarker testing}

Samples obtained by EBUS-TBNA are essentially cytological materials. Using several techniques, such as the "tissue coagulation clot method" or "cell block" making, the sample can be used for histological evaluation including immunohistochemistry. ${ }^{27,28}$ In combination with immunohistochemistry, the rate of non-small cell lung cancer not otherwise specified is low, ${ }^{29}$ and the majority of the samples can be used to diagnose the subtypes of lung cancer.

Moreover, the EBUS-TBNA samples can be used for tests using several biomarkers if an adequate sample is obtained. ${ }^{30,31}$ Detection of gene mutations, including epidermal growth factor receptor and K-Ras, and of aberrant fusion genes, such as ALK fusion gene, can be done using EBUSTBNA samples. ${ }^{32-35}$ EBUS-TBNA can be repeated during treatment, so EBUS-TBNA samples may play an important role in exploration of drug-resistance mechanisms. ${ }^{36}$ We recently demonstrated that transbronchial biopsy needle rinse solution (ultra-micro sample) can be used for multiplex polymerase chain reaction with the same accuracy as conventional biopsy samples. ${ }^{37}$ In the era of biomarker and molecular-targeted management in clinical oncology, multiple biomarker testing is quite important in tailoring treatment for the individual patient, EBUS-TBNA should play a pivotal role in practice. ${ }^{38,39}$

\section{Training in EBUS-TBNA}

Training is mandatory to obtain a high diagnostic yield, and an adequate amount of sample must be obtained for multimodal testing in EBUS-TBNA. There is a learning curve for EBUS-TBNA, ${ }^{40}$ and basic training is needed to be able to perform this technique, such as a training model and simulators. ${ }^{41}$ The development of an EBUS-TBNA training program and training model are important for trainees, and recent data suggest that the early use of a virtual reality simulator improves the skills and satisfaction of trainees. ${ }^{42}$ Another important tool for EBUS-TBNA training is evaluating EBUS skills. ${ }^{43}$ The quality of EBUS-TBNA has been evaluated using a large registry in the USA, which has provided a benchmark for this procedure and may help in quality control. ${ }^{44,45}$ 
Given the increasing number of EBUS-TBNA procedures being performed, we need to reconsider the education and training for bronchoscopic procedures. ${ }^{46}$ Recently, we introduced a preliminary training program that consists of multistep lessons in a tandem trainee and trainer setting. ${ }^{47}$ Twelve successful needle punctures is the minimum for the trainee to obtain a satisfactory diagnostic yield. We need to identify the optimal education and training program for the next-generation bronchoscopist.

\section{Conclusion}

With the introduction of EBUS-TBNA, the paradigm has shifted for nodal staging of patients with lung cancer. The gold standard modality for this purpose, ie, mediastinoscopy, is gradually being replaced with EBUS-TBNA, and this method is the best first test for patients with radiologically suspicious lymph nodes. In addition, samples obtained by EBUS-TBNA can be used for molecular testing, which is useful for selecting appropriate candidates for moleculartargeted therapy. Therefore, EBUS-TBNA plays a pivotal role in the diagnosis and treatment of lung cancer.

\section{Disclosure}

The authors report no conflicts of interest in this work.

\section{References}

1. Silvestri GA, Gonzalez AV, Jantz MA, et al. Methods for Staging NonSmall Cell Lung Cancer: Diagnosis and Management of Lung Cancer. 3rd ed: American College of Chest Physicians evidence-based clinical practice guidelines. Chest. 2013;143(Suppl 5):e211S-e250S.

2. Yasufuku K, Chiyo M, Sekine Y, et al. Real-time endobronchial ultrasound-guided transbronchial needle aspiration of mediastinal and hilar lymph nodes. Chest. 2004;126:122-128.

3. Fujiwara T, Yasufuku K, Nakajima T, et al. The utility of sonographic features during endobronchial ultrasound-guided transbronchial needle aspiration for lymph node staging in patients with lung cancer. Chest. 2010;138:641-647.

4. Tournoy KG, Annema JT, Krasnik M, Herth FJ, van Meerbeeck JP. Endoscopic and endobronchial ultrasonography according to the proposed lymph node map definition in the seventh edition of the tumor, node, metastasis classification for lung cancer. J Thorac Oncol. 2009;4: $1576-1584$.

5. Gu P, Zhao YZ, Jiang LY, Zhang W, Xin Y, Han BH. Endobronchial ultrasound-guided transbronchial needle aspiration for staging of lung cancer: a systematic review and meta-analysis. Eur J Cancer. 2009;45: 1389-1396.

6. Varela-Lema L, Fernández-Villar A, Ruano-Ravina A. Effectiveness and safety of endobronchial ultrasound-transbronchial needle aspiration: a systematic review. Eur Respir J. 2009;33:1156-1164.

7. Adams K, Shah PL, Edmonds L, Lim E. Test performance of endobronchial ultrasound and transbronchial needle aspiration biopsy for mediastinal staging in patients with lung cancer: systematic review and meta-analysis. Thorax. 2009;64:757-762.

8. Gupta NC, Graeber GM, Bishop HA. Comparative efficacy of positron emission tomography with fluorodeoxyglucose in evaluation of small $(<1 \mathrm{~cm})$, intermediate ( 1 to $3 \mathrm{~cm})$, and large $(>3 \mathrm{~cm})$ lymph node lesions. Chest. 2000;117:773-778.
9. Gould MK, Kuschner WG, Rydzak CE, et al. Test performance of positron emission tomography and computed tomography for mediastinal staging in patients with non-small-cell lung cancer: a meta-analysis. Ann Intern Med. 2003;139:879-892.

10. Sayar A, Citak N, Metin M, etal. Comparison of video-assisted mediastinoscopy and video-assisted mediastinoscopic lymphadenectomy for lung cancer. Gen Thorac Cardiovasc Surg. 2011;59:793-798.

11. Detterbeck FC, Jantz MA, Wallace M, Vansteenkiste J, Silvestri GA; American College of Chest Physicians. Invasive Mediastinal Staging of Lung Cancer: ACCP Evidence-Based Clinical Practice Guidelines. 2nd ed. Chest. 2007;132(Suppl 3):e400S-e419S.

12. Keller S, Pearson FG, Cooper JD, et al. Mediastinal lymph node dissection. In: Ginsberg RJ, Hiebert CA, Patterson GA, Urschel HC, editors. Thoracic Surgery. 2nd ed. New York, NY, USA: Churchill Livingstone; 2002.

13. Shrager JB. Mediastinoscopy: still the gold standard. Ann Thorac Surg. 2010;89:S2084-S2089.

14. Yasufuku K, Nakajima T, Motoori K, et al. Comparison of endobronchial ultrasound, positron emission tomography, and CT for lymph node staging of lung cancer. Chest. 2006;130:710-718.

15. Bin H, Seok K, Hee SL, et al. Application of endobronchial ultrasoundguided transbronchial needle aspiration following integrated PET/CT in mediastinal staging of potentially operable non-small cell lung cancer. Chest. 2009;135:1280-1287.

16. Yasufuku K, Nakajima T, Waddell T, Keshavjee S, Yoshino I. Endobronchial ultrasound-guided transbronchial needle aspiration for differentiating N0 versus N1 lung cancer. Ann Thorac Surg. 2013;96:1756-1760.

17. Vilmann P, Krasnik M, Larsen SS, Jacobsen GK, Clementsen P. Transesophageal endoscopic ultrasound-guided fine-needle aspiration (EUS-FNA) and endobronchial ultrasound-guided transbronchial needle aspiration (EBUS-TBNA) biopsy: a combined approach in the evaluation of mediastinal lesions. Endoscopy. 2005;37:833-839.

18. Sharples LD, Jackson C, Wheaton E, et al. Clinical effectiveness and cost-effectiveness of endobronchial and endoscopic ultrasound relative to surgical staging in potentially resectable lung cancer: results from the ASTER randomised controlled trial. Health Technol Assess. 2012;16:1-75, iii-iv.

19. Yasufuku K, Pierre A, Darling G, et al. A prospective controlled trial of endobronchial ultrasound-guided transbronchial needle aspiration compared with mediastinoscopy for mediastinal lymph node staging of lung cancer. J Thorac Cardiovasc Surg. 2011;142:1393-1400.

20. Lewis SZ, Diekemper R, Addrizzo-Harris DJ. Methodology for Development of Guidelines for Lung Cancer: Diagnosis and Management of Lung Cancer. 3rd ed: American College of Chest Physicians evidence-based clinical practice guidelines. Chest. 2013;143(Suppl 5):41S-50S

21. Wada H, Nakajima T, Yasufuku K, et al. Lymph node staging by endobronchial ultrasound-guided transbronchial needle aspiration in patients with small cell lung cancer. Ann Thorac Surg. 2010;90: 229-234.

22. Herth FJ, Annema JT, Eberhardt R, et al. Endobronchial ultrasound with transbronchial needle aspiration for restaging the mediastinum in lung cancer. J Clin Oncol. 2008;26:3346-3350.

23. Sara CC, Frank CD. A systematic review of restaging after induction therapy for stage IIIa lung cancer: prediction of pathologic stage. J Thorac Oncol. 2010;5:389-398.

24. Anraku M, Pierre AF, Nakajima T, et al. Endobronchial ultrasoundguided transbronchial needle aspiration in the management of previously treated lung cancer. Ann Thorac Surg. 2011;92:251-255.

25. Nakajima T, Yasufuku K, Kurosu K, et al. The role of EBUS-TBNA for the diagnosis of sarcoidosis - comparisons with other bronchoscopic diagnostic modalities. Respir Med. 2009;103:1796-1800.

26. Yamamoto T, Sakairi Y, Nakajima T, et al. Comparison between endobronchial ultrasound-guided transbronchial needle aspiration and $18 \mathrm{~F}$-fluorodeoxyglucose positron emission tomography in the diagnosis of postoperative nodal recurrence in patients with lung cancer. Eur $J$ Cardiothorac Surg. In press 2014. [Epub ahead of print.] 
27. Nakajima T, Yasufuku K, Iyoda A, et al. The evaluation of lymph node metastasis by endobronchial ultrasound-guided transbronchial needle aspiration: crucial for selection of surgical candidates with metastatic lung tumors. J Thorac Cardiovasc Surg. 2007;134:1485-1490.

28. Nakajima T, Yasufuku K, Wong M, et al. Histological diagnosis of mediastinal lymph node metastases from renal cell carcinoma by endobronchial ultrasound-guided transbronchial needle aspiration. Respirology. 2007;12:302-303.

29. Navani N, Brown JM, Nankivell M, et al. Suitability of endobronchial ultrasound-guided transbronchial needle aspiration specimens for subtyping and genotyping of non-small cell lung cancer: a multicenter study of 774 patients. Am J Respir Crit Care Med. 2012;185:1316-1322.

30. Nakajima T, Yasufuku K, Suzuki M, et al. Assessment of epidermal growth factor receptor mutation by endobronchial ultrasound-guided transbronchial needle aspiration. Chest. 2007;132:597-602.

31. Schuurbiers OC, Looijen-Salamon MG, Ligtenberg MJ, van der Heijden HF. A brief retrospective report on the feasibility of epidermal growth factor receptor and KRAS mutation analysis in transesophageal ultrasound- and endobronchial ultrasound-guided fine needle cytological aspirates. J Thorac Oncol. 2010;5:1664-1667.

32. Garcia-Olive I, Monso E, Andreo F, et al. Endobronchial ultrasoundguided transbronchial needle aspiration for identifying EGFR mutations. Eur Respir J. 2010;35:391-395.

33. van Eijk R, Licht J, Schrumpf M, et al. Rapid KRAS, EGFR, BRAF and PIK3CA mutation analysis of fine needle aspirates from non-small-cell lung cancer using allele-specific qPCR. PLoS One. 2011;6:e17791.

34. Santis G, Angell R, Nickless G, et al. Screening for EGFR and KRAS mutations in endobronchial ultrasound derived transbronchial needle aspirates in non-small cell lung cancer using COLD-PCR. PLoS One. 2011;6:e25191.

35. Sakairi Y, Nakajima T, Yasufuku K, et al. EML4-ALK fusion gene assessment using metastatic lymph node samples obtained by endobronchial ultrasound-guided transbronchial needle aspiration. Clin Cancer Res. 2010;16:4938-4945.

36. Choi Y, Soda M, Yamashita Y, et al. EML4-ALK mutations in lung cancer that confer resistance to ALK inhibitors. $N$ Engl $J$ Med. 2010;363:1734-1739.

37. Sakairi Y, Nakajima T, Yoshida S, et al. Transbronchial biopsy needle rinse solution used for comprehensive biomarker testing in patients with lung cancer. J Thorac Oncol. 2014;9:26-32.

38. Nakajima T, Kimura H, Takeuchi K, et al. Treatment of lung cancer with an ALK inhibitor after EML4-ALK fusion gene detection using endobronchial ultrasound-guided transbronchial needle aspiration. J Thorac Oncol. 2010;5:2041-2043.

39. Kimura $\mathrm{H}$, Nakajima $T$, Takeuchi $\mathrm{K}$, et al. ALK fusion gene positive lung cancer and 3 cases treated with an inhibitor for ALK kinase activity. Lung Cancer. 2012;75:66-72.

40. Groth SS, Whitson BA, D'Cunha J, Maddaus MA,AlsharifM,Andrade RS. Endobronchial ultrasound-guided fine-needle aspiration of mediastinal lymph nodes: a single institution's early learning curve. Ann Thorac Surg. 2008;86:1104-1109.

41. Wahidi MM, Hulett C, Pastis N, et al. Learning experience of linear endobronchial ultrasound among pulmonary trainees. Chest. 2014; 145:574-578.

42. Wahidi MM, Silvestri GA, Coakley RD, et al. A prospective multicenter study of competency metrics and educational interventions in the learning of bronchoscopy among new pulmonary fellows. Chest. 2010;137:1040-1049.

43. Davoudi M, Colt HG, Osann KE, Lamb CR, Mullon JJ. Endobronchial ultrasound skills and tasks assessment tool: assessing the validity evidence for a test of endobronchial ultrasound-guided transbronchial needle aspiration operator skill. Am J Respir Crit Care Med. 2012;186: 773-779.

44. Ost DE, Ernst A, Lei X, et al; AQuIRE Bronchoscopy Registry. Diagnostic yield of endobronchial ultrasound-guided transbronchial needle aspiration: results of the AQuIRE Bronchoscopy Registry. Chest 2011;140:1557-1566.
45. Eapen GA, Shah AM, Lei X, et al; American College of Chest Physicians Quality Improvement Registry, Education. Complications, consequences, and practice patterns of endobronchial ultrasound-guided transbronchial needle aspiration: results of the AQuIRE registry. Chest. 2013;143:1044-1053.

46. Kennedy MP, O'Callaghan MP, McCarthy J, Henry M. The impact of the introduction of an endobronchial ultrasound-guided transbronchial needle aspiration program on teaching of conventional bronchoscopic sampling techniques in an academic institution. Am J Respir Crit Care Med. 2013;188:255.

47. Sakairi Y, Saegusa F, Yoshida S, Takiguchi Y, Tatsumi K, Yoshino I. Evaluation of a learning system for endobronchial ultrasound-guided transbronchial needle aspiration. Respir Investig. 2012;50:46-53.

48. Yasufuku K, Chiyo M, Koh E, et al. Endobronchial ultrasound guided transbronchial needle aspiration for staging of lung cancer. Lung Cancer. 2005;50:347-354.

49. Herth FJ, Ernst A, Eberhardt R, Vilmann P, Dienemann H, Krasnik M. Endobronchial ultrasound-guided transbronchial needle aspiration of lymph nodes in the radiologically normal mediastinum. Eur Respir $J$. 2006;28:910-914.

50. Herth FJ, Eberhardt R, Krasnik M, Ernst A. Endobronchial ultrasoundguided transbronchial needle aspiration of lymph nodes in the radiologically and positron emission tomography- normal mediastinum in patients with lung cancer. Chest. 2008;133:887-891.

51. Lee HS, Lee GK, Lee HS, et al. Real-time endobronchial ultrasoundguided transbronchial needle aspiration in mediastinal staging of nonsmall cell lung cancer: how many aspirations per target lymph node station? Chest. 2008;134:368-374.

52. Wallace MB , Pascual JM , Raimondo M , et al. Minimally invasive endoscopic staging of suspected lung cancer. JAMA. 2008; 299:540-546.

53. Bauwens O, Dusart M, Pierard P, et al. Endobronchial ultrasound and value of PET for prediction of pathological results of mediastinal hot spots in lung cancer patients. Lung Cancer. 2008;61:356-361.

54. Hwangbo B, Kim SK, Lee HS, et al. Application of endobronchial ultrasound-guided transbronchial needle aspiration following integrated PET/CT in mediastinal staging of potentially operable non-small cell lung cancer. Chest. 2009;135:1280-1287.

55. Szlubowski A, Kuzdzał J, Kołodziej M, et al . Endobronchial ultrasoundguided needle aspiration in the non-small cell lung cancer staging. Eur J Cardiothorac Surg. 2009;35:332-335.

56. Rintoul RC, Tournoy KG, El Daly H, et al . EBUS-TBNA for the clarifi cation of PET positive intra-thoracic lymph nodes-an international multi-centre experience. J Thorac Oncol. 2009;4:44-48.

57. Fielding D, Windsor M. Endobronchial ultrasound convexprobe transbronchial needle aspiration as the first diagnostic test in patients with pulmonary masses and associated hilar or mediastinal nodes. Intern Med J. 2009;39:435-440.

58. Herth FJ, Krasnik M, Kahn N, Eberhardt R, Ernst A. Combined endoscopic-endobronchial ultrasound-guided fine-needle aspiration of mediastinal lymph nodes through a single bronchoscope in 150 patients with suspected lung cancer. Chest. 2010;138:790-794.

59. Cerfolio RJ, Bryant AS, Eloubeidi MA, et al. The true false negative rates of esophageal and endobronchial ultrasound in the staging of mediastinal lymph nodes in patients with nonsmall cell lung cancer. Ann Thorac Surg. 2010;90:427-434.

60. Hwangbo B, Lee GK, Lee HS, et al. Transbronchial and transesophageal fi ne-needle aspiration using an ultrasound bronchoscope in mediastinal staging of potentially operable lung cancer. Chest. 2010;138:795-802.

61. Memoli JS, El-Bayoumi E, Pastis NJ, et al. Using endobronchial ultrasound features to predict lymph node metastasis in patients with lung cancer. Chest. 2011;140:1550-1556.

62. Steinfort DP, Hew MJ, Irving LB. Bronchoscopic evaluation of the mediastinum using endobronchial ultrasound: a description of the first 216 cases carried out at an Australian tertiary hospital. Intern Med J. 2011;41:815-824. 


\section{Publish your work in this journal}

Lung Cancer: Targets and Therapy is an international, peer-reviewed, open access journal focusing on lung cancer research, identification of therapeutic targets and the optimal use of preventative and integrated treatment interventions to achieve improved outcomes, enhanced survival and quality of life for the cancer patient. Specific topics covered in the journal include: Epidemiology, detection and screening; Cellular research and biomarkers; Identification of biotargets and agents with novel mechanisms of action; Optimal clinical use of existing anticancer agents, including combination therapies; Radiation and surgery; Palliative care; Patient adherence, quality of life, satisfaction; Health economic evaluations. The manuscript management system is completely online and includes a very quick and fair peer-review system. Visit http://www.dovepress.com/testimonials.php to read real quotes from published authors.

Submit your manuscript here: http://www.dovepress.com/lung-cancer-targets--therapy-journal 